\title{
Effects of Different Dietary Lipid Levels on the Growth Performance, Body Composition and Digestive Enzymes of the Dog Conch, Laevistrombus canarium
}

\author{
Jen-Hong Chu', Ya-Wen Lan², Shyn-Shin Sheen ${ }^{3}$ and Angela Chien ${ }^{3 *}$ \\ ${ }^{1}$ Department of Aquaculture, National Pingtung University of Science and Technology, \\ Pingtung 91201, Taiwan \\ ${ }^{2}$ Marine Life Propagation Station, Penghu County, Taiwan \\ ${ }^{3}$ Department of Aquaculture, National Taiwan Ocean University, Keelung, Taiwan, \\ R.O.C.
}

\begin{abstract}
A B S T R A C T
A feeding experiment investigated the effects of dietary lipid levels on the growth, muscle composition and digestive enzyme of $0.28 \mathrm{~g}$ Laevistrombus canarium. Five semi-purified diets containing $0 \%$ (L0), $2 \%$ (L2), 4\% (L4), 6\% (L6), and 12\% (L12) lipids were formulated. Each diet was randomly assigned to three replicate groups of $L$. canarium larvae. The final weight, weight gain percentage and specific growth rate of $L$. canarium larvae fed with diets L6 and L12 were significantly higher than those of larvae fed with diets L0, L2 and L4. The feed conversion ratio (FCR) of $L$. canarium larvae fed with treatment diets was significantly lower than that of conch fed with control diet. The minimum dietary n-3 highly unsaturated fatty acid (HUFA) (C20:5n-3 + C22:6n-3) requirement for $L$. canarium was $19.59 \%$ of total lipid. Lipase activity in soft body increased with an increasing dietary lipid level, but amylase activity was not significantly affected by the dietary lipid level. Based on a broken-line of the final weight of $L$. canarium larvae, the optimum dietary lipid levels were 5.6\%.
\end{abstract}

Article Information
Received 24 May 2020
Revised 20 June 2020
Accepted 27 June 2020
Available online 16 June 2021
Authors' Contribution
JHC supervised the research and
prepared manuscript. YWL conducted
the feeding trial. SSS provided all
materials for the research. AC helped
in statistical analysis and helped in
manuscript revision.
Key words
Laevistrombus canarium, Lipid, Fatty
acids, Weight gain, Dog conch

\section{INTRODUCTION}

$L$ aevistrombus canarium, commonly known as the $\mathrm{dog}$ conch, is a marine gastropod mollusc in the family Strombidae. L. canarium is a highly valued animal species in Asian countries, including Taiwan. It is an Indo-Pacific species naturally distributed from India and Sri Lanka to Melanesia, Australia, and southern Japan (Man et al., 1998; Poutiers, 1998). In many parts of Southeast Asia, the flesh of $L$. canarium is a staple food for human consumption (Cob et al., 2008). The shell can be ornamental value (Purchon and Purchon, 1981) and used as sinkers for nets by fisheries (Poutiers, 1998). Due to its high economic value, $L$. canarium has been overexploited and overfished in many areas. Therefore, several ecologists have recommended reducing exploitation rates to maintain the sustainability of this natural resource (Cob et al., 2009a). In Taiwan, the consumption of L. canarium has increased year by year; therefore, the Marine Life Propagation Station in Penghu County, Taiwan released

\footnotetext{
Corresponding author: angelachien1221@gmail.com 0030-9923/2021/0005-1649 \$ 9.00/0

Copyright 2021 Zoological Society of Pakistan
}

48,000 L. canarium larvae into the wild in 2018. Unfortunately, catch of large $L$. canarium individuals has become an increasingly difficult task in the waters around Taiwan where this species inhabits. The mass production technology of $L$. canarium larvae has been established since 2009 (Cob et al., 2009b), but seed production is still inconsistent and of insufficient quantity to meet the high demands of grow-out fish. L. canarium larval development and survival are most affected by several environmental conditions, such as temperature and food sources, particularly, food quality and availability (Cob et al., 2009c). L. canarium lives on muddy and sandy bottoms in its wild habitat, where most food source are algae and detritus. To develop this species on an economic scale, background study of nutritional requirements should be established, such as the amounts of protein (Chu et al., 2018), lipids, carbohydrates, vitamins, and minerals.

Lipids are one of the essential nutritional elements required for animal development and growth. Lipids play several roles, such as providing energy, phospholipids, sterols, fat-soluble vitamins, and essential fatty acids (Watanabe, 1982). Fatty acids are important constituents of cell membranes in the brain and retina, particularly in the larval and juvenile stages (Chu and Sheen, 2016). 
There are protein-sparing effects of non-protein nutrients; for example, when dietary lipids are in an inadequate supply, proteins might be used as an energy source and thus would reduce the utilization of protein for animal growth. Therefore, the dietary energy supply form lipid for animal growth not only improves protein utilization but also reduces feed costs and limits ammonia production (Vergara et al., 1999).

The lipid requirements of mollusk species may differ from different species and in different life stages of mollusks (Gallager et al., 1986). Haliotis discus hannai weighing 4.36 and $0.39 \mathrm{~g}$ fed with diets containing $5 \%$ and $3.11 \% \sim 7.09 \%$ lipids, respectively, achieved optimal growth performance (Uki et al., 1985; Mai et al., 1995). Babylonia areolata weighing 0.1 and $0.16 \mathrm{~g}$ fed diets containing $10 \%$ and $6.54 \%$ lipids, respectively, achieved optimal growth performance (Chaitanawisuti et al., 2011; Zhou et al., 2007). For $0.59 \mathrm{~g}$ abalone Haliotis tuberculata, the optimal dietary lipid level was $3.11 \%$ (Mai et al., 1995). The size of mollusks mentioned above was large enough to digest the artificial diets.

Lipid, which play important roles in the physiological and nutritional status provide fatty acids for the successful metamorphosis of mollusk larval stages (Gallager et al., 1986). However, most studies relevant to the quantitative lipid requirements and their utilization is available for abalone, with little information on conch. Therefore, it is necessary to develop a dietary lipid requirement for $0.28 \mathrm{~g}$ L. canarium larvae.

\section{MATERIALS AND METHODS}

Five isonitrogenous (46.4\%) and isoenergetic (321 $\mathrm{kcal} / 100 \mathrm{~g}$ ) experimental diets were formulated to contain $0 \%$ (L0), 2\% (L2), 4\% (L4), 6\% (L6), and 12\% (L12) lipids. Casein and fish meal were served as protein sources. Before formulation of the diets, the endogenous lipid in fish meal was extracted and removed using hot ethanol $(1: 1, \mathrm{w} / \mathrm{v})$ in five successive treatments. The lipid source was a mixture of fish oil and corn oil $(2: 1, w / w), \alpha$-starch was added as a carbohydrate source and binder, and dextrin was used to adjust the energy level. Cellulose was included in the diets to balance the dietary compositions. A hammer mill was used to grind all ingredients into small particles that could pass through a $150-\mu \mathrm{m}$ mesh sieve. Water was added approximately $20 \%$ of the mash dry weight to form a moist dough. The dough was then cold-extruded through a chopper (3.0-mm die diameter) to produce pellets. The pellets were dried at $60{ }^{\circ} \mathrm{C}$ for $12 \mathrm{~h}$ to approximately $10 \%$ moisture content. The experimental diets were stored at $4^{\circ} \mathrm{C}$ in a refrigerator until use.

The proximate compositions of the experimental diets and muscle of $L$. canarium were analyzed based on AOAC (1984) methods. Crude protein was determined with a Kjeltec semi-autoanalyzer model 1007 (Tecator, Sweden). Crude lipid was determined by the chloroform-methanol $(2: 1, \mathrm{v} / \mathrm{v})$ extraction method (Folch et al., 1957). Moisture and ash were determined by conventional methods using a $200{ }^{\circ} \mathrm{C}$ oven and a muffle furnace. The crude protein of the experimental diets ranged from $46.24 \%$ to $46.26 \%$ (dry weight). Crude lipid analyses indicated that the diets formulated to contain $0 \%, 2 \%, 4 \%, 6 \%$, and $12 \%$ total lipids actually contained $0.16 \%, 2.19 \%, 4.18 \%, 6.15 \%$, and $12.19 \%$, respectively (Table I).

Table I. Ingredient composition of dietary treatments for Laevistrombus canarium.

\begin{tabular}{|c|c|c|c|c|c|}
\hline \multirow[t]{2}{*}{ Ingredient (\%) } & \multicolumn{5}{|c|}{ Dietary level of lipid (\% dry weight) } \\
\hline & $\mathbf{0 \%}$ & $2 \%$ & $4 \%$ & $6 \%$ & $12 \%$ \\
\hline Casein & 30 & 30 & 30 & 30 & 30 \\
\hline Fish meal & 23.73 & 23.73 & 23.73 & 23.73 & 23.73 \\
\hline Oil $^{1}$ & 0 & 2 & 4 & 6 & 12 \\
\hline Lecithin & 1 & 1 & 1 & 1 & 1 \\
\hline Yeast & 1 & 1 & 1 & 1 & 1 \\
\hline$\alpha$-Starch & 2 & 2 & 2 & 2 & 2 \\
\hline Dextrin & 32.0 & 27.5 & 23 & 18.5 & 5 \\
\hline Vitamin $^{2}$ & 2 & 2 & 2 & 2 & 2 \\
\hline Vitamin C & 0.03 & 0.03 & 0.03 & 0.03 & 0.03 \\
\hline Minerals $^{3}$ & 1 & 1 & 1 & 1 & 1 \\
\hline Cellulose & 7.24 & 9.74 & 12.24 & 14.74 & 22.24 \\
\hline \multicolumn{6}{|c|}{ Proximate analysis } \\
\hline Moisture & 10.60 & 10.57 & 10.51 & 10.1 & 10.12 \\
\hline Crude protein ${ }^{4}$ & 46.25 & 46.24 & 46.26 & 46.24 & 46.24 \\
\hline Crude lipids ${ }^{4}$ & 0.16 & 2.19 & 4.18 & 6.15 & 12.19 \\
\hline $\mathrm{Ash}^{4}$ & 6.15 & 6.45 & 6.35 & 6.24 & 6.28 \\
\hline Crude fiber ${ }^{4}$ & 9.12 & 11.05 & 14.06 & 16.45 & 24.21 \\
\hline $\mathrm{NFE}^{5}$ & 29.72 & 23.5 & 18.64 & 14.82 & 0.96 \\
\hline $\begin{array}{l}\text { Dietary energy } \\
(\mathrm{kcal} / 100 \mathrm{~g})^{6}\end{array}$ & 305.32 & 298.67 & 297.22 & 299.59 & 298.51 \\
\hline
\end{tabular}

${ }^{1}$ Fish oil: corn oil, $(2: 1 \mathrm{v} / \mathrm{v}) ;{ }^{2}$ Thiamin $\mathrm{HCl} 0.5 \%$, riboflavin $0.8 \%$, niacinamide $2.6 \%$, D-biotin $0.1 \%$, Ca-pantothenate $1.5 \%$, pyridoxine $\mathrm{HCl} 0.3 \%$, folic acid $0.5 \%$, inositol $18.1 \%$, ascorbic acid $12.1 \%$, cyanobalamin $0.1 \%$, para-aminobenzoic acid $3 \%$, BHT $0.1 \%$, and cellulose $60.3 \%$; ${ }^{3}$ Bernhart-Tomarell, modified (Bernhart and Tomarell, 1966); ${ }^{4}$ Expressed as a percent of dry weight; ${ }^{5}$ Nitrogen free extract (NFE): $[100$ - (crude protein + crude lipids + crude fiber + ash)] $(\%)$; ${ }^{6}$ Calculated digestible energy $=[4$ (\% crude protein $)+9(\%$ crude lipid $)$ $+4(\% \mathrm{NFE})]$. 
In total, 35 days after hatch $L$. canarium larvae were transported from the Marine Life Propagation Station, Penghu County to National Pingtung University of Science and Technology, Pingtung, Taiwan by air. The larvae were transported in tightly sealed bags, quarterfilled with seawater, inflated with oxygen, and enclosed in an insulated container. After 1-week of acclimation in the laboratory, L. canarium individuals weighing $0.28 \mathrm{~g}$ were randomly distributed into 15 aquarium $(45 \times 30 \times$ $30 \mathrm{~cm}$ ) containing $50 \mathrm{~L}$ of seawater with $10 \mathrm{~L}$. canarium in each aquarium. Five experimental diets were randomly assigned to three replicate aquaria.

Table II. Major fatty acid composition (\% of total fatty acids) of the experimental diets.

\begin{tabular}{|c|c|c|c|c|c|}
\hline \multirow[t]{2}{*}{ Fatty acids } & \multicolumn{5}{|c|}{ Dietary level of lipid (\% dry weight) } \\
\hline & $0 \%$ & $2 \%$ & $4 \%$ & $6 \%$ & $12 \%$ \\
\hline $14: 0$ & 6.68 & 0.03 & 0.06 & 0.08 & 0.11 \\
\hline $14: 1$ & 8.38 & 0.02 & 0.12 & 0.1 & 0.06 \\
\hline $16: 0$ & 14.99 & 13.56 & 12.03 & 13.12 & 14.62 \\
\hline $16: 1$ & 2.84 & 0.35 & 0.63 & 0.45 & 0.46 \\
\hline 18:0 & 46.86 & 44.79 & 30.97 & 35.19 & 32.24 \\
\hline $18: 1$ & 1.11 & 1.06 & 0.96 & 1.03 & 0.99 \\
\hline $18: 2 n-6$ & 1.68 & 1.95 & 1.52 & 1.56 & 1.48 \\
\hline $18: 3 n-3$ & 1.14 & 2.14 & 2.01 & 2.01 & 2.36 \\
\hline $20: 0$ & n.d. & 0.14 & 0.12 & 0.15 & 0.15 \\
\hline $20: 1$ & n.d. & 0.16 & 0.21 & 0.16 & 0.17 \\
\hline $20: 2$ & 8.01 & 0.41 & 0.29 & 0.64 & 0.65 \\
\hline $20: 3 n-6$ & 0.69 & 1.63 & 1.23 & 1.62 & 1.36 \\
\hline $20: 3 n-3$ & 2.61 & 1.62 & 16.5 & 2.06 & 2.31 \\
\hline $20: 4 n-6$ & n.d. & 13.21 & 13.21 & 15.01 & 15.21 \\
\hline $20: 5 n-3$ & n.d. & 0.83 & 1.36 & 1.03 & 1.67 \\
\hline $22: 0$ & 4.22 & 0.21 & 0.14 & 0.21 & 0.25 \\
\hline $22: 1$ & n.d. & 1.03 & 1.01 & 0.63 & 0.39 \\
\hline $22: 5 n-3$ & n.d. & 5.63 & 4.66 & 6.39 & 6.78 \\
\hline $22: 6 n-3$ & 4.47 & 11.23 & 13.57 & 18.56 & 19.12 \\
\hline SFAs & 72.75 & 58.73 & 43.32 & 48.75 & 47.37 \\
\hline MUFAs & 12.33 & 2.62 & 2.93 & 2.37 & 2.07 \\
\hline PUFAs & 14.13 & 7.75 & 21.55 & 7.89 & 8.16 \\
\hline n-3 HUFAs & 4.47 & 17.69 & 19.59 & 25.98 & 27.57 \\
\hline
\end{tabular}

SFAs, saturated fatty acids; MUFAs, monounsaturated fatty acids; PUFAs, polyunsaturated fatty acids; HUFA, highly unsaturated fatty acids; n.d., not detectable.

Triplicate groups of $L$. canarium larvae were fed with the experimental diets (at a rate of approximately $5 \%$ of their body weight) twice (08:00 and 18:00) a day by hand for 56 days. During the feeding period, the water temperature, dissolved oxygen, and salinity ranged from 27 to $28^{\circ} \mathrm{C}, 5.0$ to $5.1 \mathrm{ppm}$, and $34 \%$ o to $35 \%$, respectively. Experiment was maintained on a 12-h dark: 12-h light photoperiod. Uneaten feed and feces were siphoned out before the next feeding. At the beginning and termination of the experiment, all L. canarium were starved for 24 $\mathrm{h}$ before being weighed and the wet weights of survival individuals in each aquarium were determined. The following growth factors were calculated as described: the weight gain percentage $=100 \times\left(\mathrm{W}_{\mathrm{t}}-\mathrm{W}_{0}\right) / \mathrm{W}_{0}$; survival $\left.=100 \times\left(\mathrm{F}_{\mathrm{i}}-\mathrm{F}_{\mathrm{d}}\right) / \mathrm{F}_{\mathrm{i}}\right)$; feed conversion ratio $(\mathrm{FCR})=$ total feed intake $(\mathrm{g}) /\left(\mathrm{W}_{\mathrm{t}}-\mathrm{W}_{0}\right)(\mathrm{g})$; specific growth rate $(\mathrm{SGR})=$ $100\left(\ln \mathrm{W}_{\mathrm{t}}-\ln \mathrm{W}_{0}\right)$ / feeding days; soft muscle/shell weight ratio $(\mathrm{SB} / \mathrm{S})=100 \times\left(\mathrm{W}_{\mathrm{s}} / \mathrm{W}_{\mathrm{t}}\right)$; shell length increase $=100$ $\left(\mathrm{S}_{\mathrm{f}}-\mathrm{S}_{\mathrm{i}}\right) / \mathrm{S}_{\mathrm{i}}$; mean protein gain $(\mathrm{MPG})=\mathrm{SB}_{\mathrm{f}} \times\left(1-\mathrm{M}_{\mathrm{f}}\right)$ $\times \mathrm{P}_{\mathrm{f}}-\mathrm{SB}_{\mathrm{i}} \times\left(1-\mathrm{M}_{\mathrm{i}}\right) \times \mathrm{P}_{\mathrm{i}}$; where $\mathrm{W}_{0}$ is the initial mean body weight $(\mathrm{g}), \mathrm{W}_{\mathrm{t}}$ is the final mean body weight $(\mathrm{g}), \mathrm{W}_{\mathrm{s}}$ is the final soft-body weight $(\mathrm{g}), \mathrm{F}_{\mathrm{i}}$ is the initial L. canarium number, and $\mathrm{F}_{\mathrm{d}}$ is the number of dead L. canarium, $\mathrm{S}_{\mathrm{i}}$ is the initial $L$. canarium length $(\mathrm{mm}), \mathrm{S}_{\mathrm{f}}$ is the final $L$. canarium length (mm), $\mathrm{SB}_{\mathrm{f}, \mathrm{i}}$, is the final or initial L. canarium softbody weight $(\mathrm{g}), \mathrm{M}_{\mathrm{f}, \mathrm{i}}$ is the final or initial moisture level in the soft body (\%), and $\mathrm{P}_{\mathrm{f} . \mathrm{i}}$ is the final or initial protein level in the soft body (\%).

At the termination of the experiment, all survival L. canarium were sacrificed by immersing them in ice water, and the muscle was carefully dissected. Some of the muscle was analyzed for amylase, lipase and fatty acid profile, while others were dried in an oven at $60^{\circ} \mathrm{C}$, crushed using a homogenizer, and then stored in a refrigerator at $-20{ }^{\circ} \mathrm{C}$ until being analyzed. The muscle and liver were weighed to calculate the soft-body weight to shell weight ratio $(\mathrm{SB} / \mathrm{S})$, and analyzed for the proximate composition.

Diets and the muscle of survival L. canarium from each treatment were separately homogenized in chloroform/ methanol $(2: 1, \mathrm{v} / \mathrm{v})$ for $5 \mathrm{~min}$ to extract total lipids (Folch et al., 1957) and refluxed in $50 \% \mathrm{KOH}$ for $40 \mathrm{~min}$. The saponified lipids were then methylated by refluxing for $20 \mathrm{~min}$ in $2 \mathrm{ml} \mathrm{14 \%}$ boron-trifluoride in methanol $\left(\mathrm{BF}_{3}-\right.$ $\mathrm{MeOH})$ as described by Metcalfe and Schmitz (1961) and then extracted with $50 \mathrm{ml}$ ether and $20 \mathrm{ml}$ distilled water in a separatory funnel. Fatty acid methyl esters (FAMEs) were analyzed using gas-liquid chromatography in a Trace GC 2000 instrument equipped with a flame ionization detector. The FAMEs were separated on a Restek's capillary column $(30 \mathrm{~m} \times 0.28 \mathrm{~mm}, 0.25-\mu \mathrm{m}$ film thickness, Stabilwax, ST, USA) isothermally at $208{ }^{\circ} \mathrm{C}$. The injection and detector temperatures were maintained at 250 and $200{ }^{\circ} \mathrm{C}$, respectively. Nitrogen was used as the carrier gas. 
Table III. Initial weight, final weight, weight gain, specific growth rate (SGR), feed conversion ratio (FCR), and survival of $L$. canarium.

\begin{tabular}{lllllll}
\hline Dietary level of lipid & Initial weight $(g)$ & Final weight(g) & Weight gain (\%) & FCR & SGR (\%) & Survival (\%) \\
\hline $0 \%$ & $0.28 \pm 0.00$ & $0.59 \pm 0.08^{\mathrm{d}}$ & $125.86 \pm 30.66^{\mathrm{d}}$ & $5.79 \pm 1.53^{\mathrm{a}}$ & $1.44 \pm 0.24^{\mathrm{d}}$ & 100 \\
$2 \%$ & $0.28 \pm 0.00$ & $1.09 \pm 0.09^{\mathrm{c}}$ & $317.31 \pm 34.21^{\mathrm{c}}$ & $3.46 \pm 0.34^{\mathrm{b}}$ & $2.55 \pm 0.15^{\mathrm{c}}$ & 100 \\
$4 \%$ & $0.28 \pm 0.00$ & $1.98 \pm 0.10^{\mathrm{b}}$ & $660.20 \pm 33.93^{\mathrm{b}}$ & $3.55 \pm 0.21^{\mathrm{b}}$ & $3.62 \pm 0.08^{\mathrm{b}}$ & 100 \\
$6 \%$ & $0.28 \pm 0.00$ & $2.42 \pm 0.20^{\mathrm{a}}$ & $830.25 \pm 74.09^{\mathrm{a}}$ & $2.46 \pm 0.10^{\mathrm{b}}$ & $3.98 \pm 0.14^{\mathrm{a}}$ & 100 \\
$12 \%$ & $0.28 \pm 0.00$ & $2.44 \pm 0.10^{\mathrm{a}}$ & $838.17 \pm 34.04^{\mathrm{a}}$ & $2.48 \pm 0.09^{\mathrm{b}}$ & $4.00 \pm 0.07^{\mathrm{a}}$ & 100 \\
\hline
\end{tabular}

a,b,c,d Means(mean \pm s.d.) in the same column with different letters significantly differ at $p<0.05$.

Fatty acids were identified by comparison with retention times of reference standards (GLC-68A, NuCheck-Prep) consisting of a mixture of saturated (SFAs) and polyunsaturated fatty acids (PUFAs).

The muscle was homogenized $(1: 9 \mathrm{w} / \mathrm{v})$ in ice-cold double distilled buffer. The homogenates were centrifuged at $30,000 \mathrm{~g}$ for $30 \mathrm{~min}$ at $4^{\circ} \mathrm{C}$ and collected the resultant supernatants stored at $-80^{\circ} \mathrm{C}$ until analysis digestive enzyme. The digestive enzyme activities were determined with a commercial kit (Spinreact, Girona, Spain, ref. 41201 for amylase, and ref.1001275 for lipase).

Data are presented as the mean \pm standard deviation. A one-way analysis of variance (ANOVA) was performed to examine differences in weight gain percentages, SGR, FCR, and data of shell growth and survival among treatments. When a significant difference was observed, Tukey's test was used to compare differences among treatment means. The significance level was set to 0.05 , and all statistical analyses were conducted using the SAS software program for Windows (V9.4, SAS Institute, Cary, NC, USA).

\section{RESULTS}

Fatty acid compositions of the diets containing different levels of lipid are presented in Table II. The diet without lipid addition contained higher proportions of SFAs and lower proportions of highly unsaturated fatty acids (HUFAs). Dietary levels of eicosapentaenoic acid (EPA) and docosahexaenoic acid (DHA) increased with increasing dietary lipid levels.

The final weight, weight gain percentage, FCR, SGR, and survival of $L$. canarium are presented in Table III. The $L$. canarium fed with diets containing $6 \%$ and $12 \%$ lipid showed significantly higher final weight, weight gain percentage and SGR than those fed with diet containing 0 , 2 and $4 \%$ lipid. L. canarium fed with the diet without lipid supplementation showed the lowest growth performance.
There is no mortality occurred during the 56-day feeding trial and survival was not affected by the different dietary treatments.

The proximate compositions of dog conch muscle are presented in Table IV. Moisture and crude protein contents of muscles ranged from 76.03 to $76.41 \%$ and 45.28 to $45.35 \%$, respectively. In contrast, the lipid contents of dog conch muscle increased with increasing dietary lipid ranging from 2.24 to $5.00 \%$.

Table IV. Proximate composition of muscle of $L$. canarium fed diets containing different levels of lipid.

\begin{tabular}{lllll}
\hline $\begin{array}{l}\text { Dietary } \\
\text { level of } \\
\text { lipid }\end{array}$ & \multicolumn{4}{c}{ Muscle composition (\% dry weight) } \\
\cline { 2 - 5 } & Moisture & Ash & $\begin{array}{l}\text { Crude } \\
\text { protein }\end{array}$ & $\begin{array}{l}\text { Crude } \\
\text { lipids }\end{array}$ \\
\hline $0 \%$ & $76.03 \pm 0.12^{\mathrm{c}}$ & $1.12 \pm 0.03$ & $45.35 \pm 0.05$ & $2.24 \pm 0.07^{\mathrm{e}}$ \\
$2 \%$ & $76.41 \pm 0.02^{\mathrm{a}}$ & $1.09 \pm 0.03$ & $45.33 \pm 0.02$ & $3.12 \pm 0.03^{\mathrm{d}}$ \\
$4 \%$ & $76.33 \pm 0.04^{\mathrm{ab}}$ & $1.11 \pm 0.04$ & $45.28 \pm 0.07$ & $4.01 \pm 0.04^{\mathrm{c}}$ \\
$6 \%$ & $76.14 \pm 0.18^{\mathrm{bc}}$ & $1.10 \pm 0.04$ & $45.33 \pm 0.03$ & $4.15 \pm 0.03^{\mathrm{b}}$ \\
$12 \%$ & $76.30 \pm 0.08^{\mathrm{ab}}$ & $1.10 \pm 0.03$ & $45.34 \pm 0.02$ & $5.00 \pm 0.02^{\mathrm{a}}$ \\
\hline $\begin{array}{l}\mathrm{a}, \mathrm{b}, \mathrm{c}, \mathrm{d}, \mathrm{e} \\
\text { significantly differ at } p<0.05 .\end{array}$
\end{tabular}

Fatty acid profiles of dog conch muscle are presented in Table V. Percentages of C14:0, C14:1, C18:2n-6 and C20:0 in the muscle of $L$. canarium fed with the diet without lipid supplementation were significantly higher than those fed with the other treatment diets. Percentages of C20:5n-3, C22:5n-3 and C22:6n-3 of the muscle of L. canarium fed with the diets containing 4,6 and $12 \%$ lipid were significantly higher than those fed the other treatment diets. The percentage of C20:4n- 6 of the muscle of $L$. canarium fed with the diet containing $12 \%$ lipid was significantly lower than those of dog conch fed with the other diets. 
Table V. Major fatty acid composition (\% of total fatty acids) of muscle of $L$. canarium.

\begin{tabular}{|c|c|c|c|c|c|}
\hline \multirow[t]{2}{*}{ Fatty acid } & \multicolumn{5}{|c|}{ Dietary level of lipid (dry weight \%) } \\
\hline & $0 \%$ & $2 \%$ & $4 \%$ & $6 \%$ & $12 \%$ \\
\hline 14:0 & $12.36 \pm 0.03^{\mathrm{a}}$ & $12.12 \pm 0.16^{b}$ & $11.41 \pm 0.06^{\mathrm{c}}$ & $5.41 \pm 0.05^{\mathrm{d}}$ & $5.04 \pm 0.09^{\mathrm{e}}$ \\
\hline $14: 1$ & $0.14 \pm 0.01^{\mathrm{a}}$ & $0.10 \pm 0.02^{\mathrm{b}}$ & $0.06 \pm 0.01^{\mathrm{c}}$ & $0.07 \pm 0.01^{\mathrm{c}}$ & $0.07 \pm 0.01^{\mathrm{c}}$ \\
\hline $16: 0$ & $10.81 \pm 0.20^{\mathrm{d}}$ & $23.55 \pm 0.06^{\mathrm{a}}$ & $3.73 \pm 0.09^{\mathrm{e}}$ & $19.55 \pm 0.26^{\mathrm{c}}$ & $21.09 \pm 0.23^{\mathrm{b}}$ \\
\hline $16: 1$ & $6.81 \pm 0.07^{\mathrm{d}}$ & $8.67 \pm 0.03^{\mathrm{c}}$ & $14.21 \pm 0.40^{\mathrm{a}}$ & $12.78 \pm 0.20^{\mathrm{b}}$ & $13.87 \pm 0.20^{\mathrm{a}}$ \\
\hline 18:0 & $24.20 \pm 0.06^{\mathrm{a}}$ & $16.16 \pm 0.17^{b}$ & $10.83 \pm 0.67^{\mathrm{c}}$ & $5.54 \pm 0.17^{\mathrm{e}}$ & $6.88 \pm 0.18^{\mathrm{d}}$ \\
\hline $18: 1$ & $9.87 \pm 0.16^{\mathrm{e}}$ & $14.17 \pm 0.14^{\mathrm{c}}$ & $22.78 \pm 0.81^{\mathrm{a}}$ & $12.55 \pm 1.02^{\mathrm{d}}$ & $19.87 \pm 0.35^{\mathrm{b}}$ \\
\hline $18: 2 n-6$ & $0.93 \pm 0.06^{\mathrm{a}}$ & $0.25 \pm 0.02^{\mathrm{c}}$ & $0.35 \pm 0.03^{\mathrm{c}}$ & $0.47 \pm 0.13^{\mathrm{b}}$ & $0.28 \pm 0.02^{\mathrm{c}}$ \\
\hline $18: 3 n-3$ & $0.37 \pm 0.02^{\mathrm{c}}$ & $0.09 \pm 0.01^{\mathrm{d}}$ & $0.16 \pm 0.02^{\mathrm{cd}}$ & $2.17 \pm 0.20^{\mathrm{a}}$ & $1.70 \pm 0.24^{\mathrm{b}}$ \\
\hline $20: 0$ & $21.07 \pm 0.14^{\mathrm{a}}$ & $0.37 \pm 0.02^{\mathrm{d}}$ & $0.79 \pm 0.02^{\mathrm{c}}$ & $4.56 \pm 0.35^{\mathrm{b}}$ & $0.98 \pm 0.02^{\mathrm{c}}$ \\
\hline $20: 1$ & $0.37 \pm 0.06^{\mathrm{d}}$ & $1.53 \pm 0.04^{\mathrm{a}}$ & $1.07 \pm 0.02^{\mathrm{b}}$ & $0.36 \pm 0.01^{\mathrm{d}}$ & $0.55 \pm 0.04^{\mathrm{c}}$ \\
\hline $20: 2 n-6$ & $0.11 \pm 0.02^{\mathrm{d}}$ & $0.56 \pm 0.10^{\mathrm{b}}$ & $0.31 \pm 0.05^{\mathrm{c}}$ & $3.37 \pm 0.17^{\mathrm{a}}$ & $0.36 \pm 0.01^{\mathrm{c}}$ \\
\hline $20: 3 n-6$ & n.d. & $0.15 \pm 0.03^{\mathrm{c}}$ & $0.19 \pm 0.02^{\mathrm{b}}$ & $0.26 \pm 0.01^{\mathrm{a}}$ & $0.14 \pm 0.01^{\mathrm{c}}$ \\
\hline $20: 3 n-3$ & n.d. & $0.12 \pm 0.03^{\mathrm{b}}$ & $0.05 \pm 0.01^{\mathrm{b}}$ & $0.43 \pm 0.04^{\mathrm{a}}$ & $0.48 \pm 0.08^{\mathrm{a}}$ \\
\hline $20: 4 n-6$ & $0.69 \pm 0.02^{\mathrm{a}}$ & $0.68 \pm 0.04^{\mathrm{a}}$ & $0.60 \pm 0.04^{b}$ & $0.70 \pm 0.01^{\mathrm{a}}$ & $0.36 \pm 0.05^{\mathrm{c}}$ \\
\hline $20: 5 n-3$ & $0.19 \pm 0.01^{\mathrm{c}}$ & $0.24 \pm 0.02^{\mathrm{b}}$ & $0.66 \pm 0.02^{\mathrm{a}}$ & $0.67 \pm 0.02^{\mathrm{a}}$ & $0.68 \pm 0.01^{\mathrm{a}}$ \\
\hline $22: 0$ & $9.92 \pm 0.12^{\mathrm{c}}$ & $13.37 \pm 0.60^{\mathrm{ab}}$ & $14.46 \pm 0.96^{\mathrm{a}}$ & $12.53 \pm 0.24^{b}$ & $8.00 \pm 0.94^{\mathrm{d}}$ \\
\hline $22: 1$ & $1.31 \pm 0.30 \mathrm{~b}^{\mathrm{c}}$ & $1.33 \pm 0.06^{\mathrm{bc}}$ & $1.49 \pm 0.23^{\mathrm{b}}$ & $1.01 \pm 0.06^{\mathrm{c}}$ & $2.66 \pm 0.26^{\mathrm{a}}$ \\
\hline $22: 5 n-3$ & $0.15 \pm 0.03^{\mathrm{c}}$ & $4.65 \pm 0.35^{\mathrm{b}}$ & $12.70 \pm 0.26^{\mathrm{a}}$ & $13.30 \pm 0.58^{\mathrm{a}}$ & $12.96 \pm 0.02^{\mathrm{a}}$ \\
\hline $22: 6 n-3$ & $0.70 \pm 0.17^{\mathrm{c}}$ & $1.62 \pm 0.14^{\mathrm{b}}$ & $4.14 \pm 0.15^{\mathrm{a}}$ & $4.26 \pm 0.08^{\mathrm{a}}$ & $4.03 \pm 0.03^{\mathrm{a}}$ \\
\hline SFAs & $78.35 \pm 0.08^{\mathrm{a}}$ & $65.57 \pm 0.60^{\mathrm{b}}$ & $41.21 \pm 1.36^{\mathrm{d}}$ & $47.59 \pm 0.23^{c}$ & $41.98 \pm 0.79^{\mathrm{d}}$ \\
\hline MUFAs & $18.49 \pm 0.10^{\mathrm{d}}$ & $25.80 \pm 0.10^{c}$ & $39.62 \pm 1.29^{\mathrm{a}}$ & $26.77 \pm 0.92^{\mathrm{c}}$ & $37.03 \pm 0.60^{\mathrm{b}}$ \\
\hline PUFAs & $1.42 \pm 0.07^{\mathrm{c}}$ & $1.16 \pm 0.13^{\mathrm{d}}$ & $1.07 \pm 0.05^{\mathrm{d}}$ & $6.70 \pm 0.19^{\mathrm{a}}$ & $2.95 \pm 0.18^{b}$ \\
\hline n-3 HUFAs & $1.05 \pm 0.19^{\mathrm{d}}$ & $6.52 \pm 0.47^{\mathrm{c}}$ & $17.5 \pm 0.16^{\mathrm{b}}$ & $18.24 \pm 0.62^{\mathrm{a}}$ & $17.68 \pm 0.02^{\mathrm{ab}}$ \\
\hline
\end{tabular}

SFAs, saturated fatty acids; MUFAs, monounsaturated fatty acids; PUFAs, polyunsaturated fatty acids; HUFAs, highly unsaturated fatty acids; n.d., not detectable.

Table VI. Effects of dietary lipid levels on the shell length increase, soft-body weight/shell weight $(\mathrm{SB} / \mathrm{S})$ ratio, and mean protein gain (MPG) of $L$. canarium fed diets containing different levels of lipid.

\begin{tabular}{llll}
\hline $\begin{array}{l}\text { Dietary level } \\
\text { of lipid }\end{array}$ & $\begin{array}{l}\text { Shell length } \\
\text { increase }(\mathbf{m m})\end{array}$ & SB/S (\%) & $\begin{array}{l}\text { MPG }(\mathrm{g} / \\
\text { shell) }\end{array}$ \\
\hline $0 \%$ & $19.79 \pm 0.22^{\mathrm{e}}$ & $0.23 \pm 0.03^{\mathrm{b}}$ & $0.02 \pm 0.00^{\mathrm{d}}$ \\
$2 \%$ & $57.22 \pm 1.65^{\mathrm{d}}$ & $0.27 \pm 0.04^{\mathrm{b}}$ & $0.07 \pm 0.00^{\mathrm{c}}$ \\
$4 \%$ & $71.18 \pm 0.67^{\mathrm{c}}$ & $0.38 \pm 0.02^{\mathrm{a}}$ & $0.12 \pm 0.00^{\mathrm{b}}$ \\
$6 \%$ & $88.43 \pm 0.55^{\mathrm{a}}$ & $0.39 \pm 0.04^{\mathrm{a}}$ & $0.13 \pm 0.00^{\mathrm{a}}$ \\
$12 \%$ & $83.04 \pm 1.87^{\mathrm{b}}$ & $0.35 \pm 0.02^{\mathrm{a}}$ & $0.13 \pm 0.00^{\mathrm{a}}$ \\
\hline
\end{tabular}

$\mathrm{a}, \mathrm{b}, \mathrm{c}, \mathrm{d}$ Means (mean \pm s.d.) in the same column with different letters significantly differ at $\mathrm{p}<0.05$.
The shell length increase, SB/S and MPG of $L$. canarium are shown in Table VI. The shell length increase of $L$. canarium fed with the diet containing $6 \%$ lipid was significantly higher than that of conch fed with the other diets, whereas the shell length increase of dog conch fed with the control diet was significantly lower than that of conch fed the other diets. The SB/S of L. canarium fed with the diets containing 4, 6 and $12 \%$ lipid was significantly higher than that of conch fed with diets containing 0 and $2 \%$ lipid. The conch fed with diets containing 6 and 12 $\%$ lipid had significantly higher MPG than those fed with other treatment diets.

The lipase and amylase of conch muscle are presented in Table VII. Lipase activity of muscle of $L$. canarium fed diets containing 4, 6 and 12\% lipid was significantly 
higher than that of conch fed with diets containing 0 and $2 \%$ lipid. However, the amylase activity was not affected by the dietary lipid levels.

Table VII. Effect of dietary lipid level on the activities of digestive enzymes of $L$. canarium fed with diets containing different levels of lipid.

\begin{tabular}{|c|c|c|}
\hline $\begin{array}{l}\text { Dietary level of } \\
\text { lipid }\end{array}$ & $\begin{array}{l}\text { Lipase (mU mg-1 } \\
\text { protein) }\end{array}$ & $\begin{array}{l}\text { Amylase }\left(\mathrm{mU} \mathrm{mg}^{-1}\right. \\
\text { protein) }\end{array}$ \\
\hline $0 \%$ & $0.16 \pm 0.01^{\mathrm{d}}$ & $2.05 \pm 0.08$ \\
\hline $2 \%$ & $0.21 \pm 0.02^{\mathrm{c}}$ & $2.07 \pm 0.07$ \\
\hline $4 \%$ & $0.29 \pm 0.02^{\mathrm{b}}$ & $2.01 \pm 0.09$ \\
\hline $6 \%$ & $0.31 \pm 0.02^{\mathrm{b}}$ & $2.05 \pm 0.05$ \\
\hline $12 \%$ & $0.35 \pm 0.02^{\mathrm{a}}$ & $2.03 \pm 0.17$ \\
\hline
\end{tabular}

a,b,c,d Means (mean \pm s.d.) in the same column with different letters significantly differ at $p<0.05$.

The broken-line analysis based on the final weight for estimating the optimal dietary lipid requirement for $L$. canarium is shown in Figure 1. The regression equations are $\mathrm{Y}=0.35 \mathrm{X}+0.47\left(\mathrm{r}^{2}=0.97\right)$ and $\mathrm{Y}_{\max }=2.43$. The broken point occurred at $5.6 \mathrm{~g} \mathrm{lipid} / 100 \mathrm{~g}$ diet was estimated to provide the adequate level of dietary lipid for L. canarium.

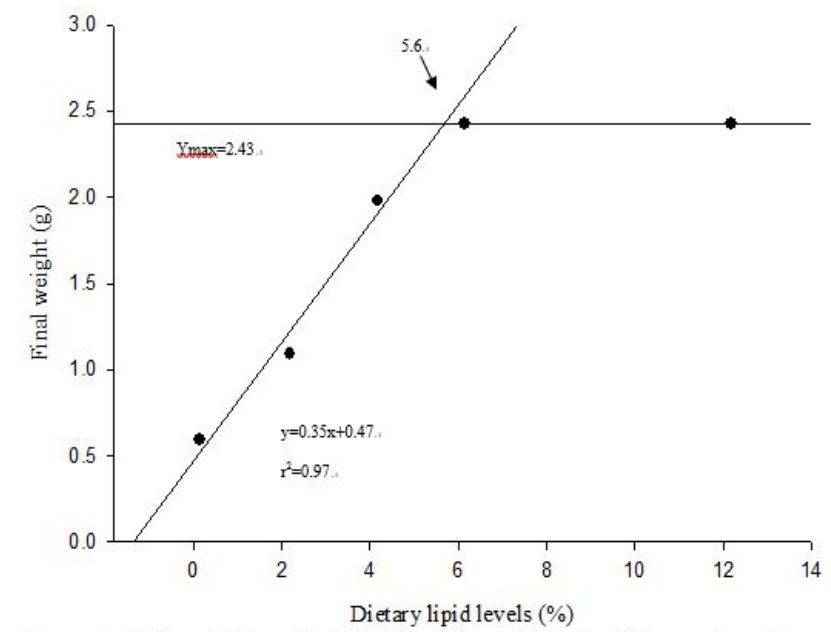

Fig. 1. Effect of dietary lipid levels on the final weight of L. canarium. The regression line that fits the dietary lipid requirement has a breakpoint at $5.6 \mathrm{~g} \mathrm{lipid} / 100 \mathrm{~g}$ diet.

\section{DISCUSSION}

Our study indicated that a dietary lipid level ranging from 6 to $12 \%$ is satisfactory for dog conch. This study supports the observed relationship of comparatively low dietary lipid levels and reduced growth performance in certain aquatic animals (NRC, 2011). The reduced growth response to low levels of dietary lipid is probably due to insufficient lipid utilization, particularly when other energy sources are available (Sheen and D'Abramo, 1991). Under these conditions, protein may serve as an energy source. Although carbohydrate can be converted into fatty acids, the quantity of carbohydrate converted into fatty acids might be insufficient for animal growth. Therefore, the growth performance of dog conch fed with the control diet without lipid addition was lower than those of dog conch fed with the diets containing lipid, although the diets were isoenergetic. The significantly lower weight gain of dog conch fed with the diet without oil probably reflects a response to insufficient levels of dietary essential fatty acids rather than the ratio itself. These results were similar to the results of other mollusk species, such as abalone, $H$. tuberculate and $H$. discus hannai (Mai et al., 1995).

Ivory shell larvae, $B$. areolate, fed with diets containing above $7.8 \%$ lipid (Zhou et al., 2007), H. asinine fed with diets containing above 6.1\% lipid (BautistaTeruel et al., 2011) and H. tuberculate and H. discuss fed with diets containing above $5 \%$ lipid (Mai et al., 1995), showed a decrease in growth performance. Diets containing high levels of lipid have the adverse effect on the weight gain of ivory shell and abalone. However, dog conch fed with the diets containing higher than $5.6 \%$ lipids showed no adverse effect on the growth performance. The magnitude of a weight gain response to different levels of lipid appears to be partially dependent on the amount of available dietary energy. Differences in response of lipid may be most pronounced at higher levels of total available energy. If a diet contains a sufficient level of non-protein energy, little protein will be used as an energy source (Huo et al., 2014). We suggest that in diets which do not satisfy the protein requirement the relative proportion of energy sources can exert a significant effect on growth.

This study tried to maintain the same dietary protein to energy ratio while changing the total levels of a dietary oil mixture and to satisfy the protein requirement by supplying the proper quality and quantity of protein. Under these conditions, the relative proportions of lipid and carbohydrate differed and the carbohydrate:lipid ratio ranged from 0.08 to 10.7. Comparable weight gain responses of juvenile dog conch to lipid levels were between 6 to 12 $\%$ and all essential fatty acid requirements were satisfied at the $6 \%$ level of the oil mixture. The significant weight gain of dog conch was observed in response to the 1.21 $\%$ dietary EPA and DHA when expressed as a percentage of the dry diet in this study. A level of dietary lipid as low as $6 \%$ can be sufficient if appropriate levels of protein, energy and essential fatty acids are provided.

There was a positive correlation between muscle 
lipid contents and dietary lipid levels in this study. Muscle lipid contents increased as dietary lipid supplementation increased. It was indicated that when dietary lipids were supplied in excess, a proportion of these lipids is deposited as body fat. This observation was similar to those in $H$. tuberculata, H. discus hannai (Mai et al., 1995), B. areolata (Zhou et al., 2007), and some marine fishes, Epinephelus bruneus (Yoshii et al., 2010), Atlantic cod (Morais et al., 2001), Epinephelus coioides, and Epinephelus lanceolatus (Chu and Sheen, 2016). Protein contents in muscle tissues of $L$. canarium were not correlated with dietary lipid levels, even though these experimental diets were isonitrogenous; this result was similar to those of abalone (Mai et al., 1995) and ivory shell (Zhou et al., 2007). The SB/S and MPG of L. canarium increased as the dietary lipid level rose to $6 \%$, but then decreased when the dietary level exceeded $6 \%$, the finding that agrees with previous results reported for ivory shell (Zhou et al., 2007). Those results also suggest mollusks seem to be able to digest and utilize dietary lipids or carbohydrates to achieve good growth parameters.

The fatty acid profiles in muscle of $L$. canarium fed diets supplemented with lipids generally reflect those of the dietary source. This is especially obvious when the dietary lipid content exceeded $4 \%$. This result was similar to several reports on abalone (Bautista-Teruel et al., 2011; Thongrod et al., 2003), hybrid tilapia (Huang et al., 1998), freshwater prawn (D'Abramo and Sheen, 1993), grouper (Chu and Sheen, 2016), Chinook salmon (Silver et al., 1993), and a snail (Lee and Lim, 2005). The increase of tissue EPA, C22:5n-3 and DHA as the level of dietary lipid increased was of particular importance. The dietary n-3 fatty acids (EPA + C22:5n-3 + DHA) ranged from 0.007 to $3.36 \%$ when expressed as a percentage of the dry diet in this study. However, there have been no studies on the essential fatty acid requirement for dog conch. The levels of EPA + C22:5n-3 + DHA (1.60 to $3.36 \%$ ) found in the diets supplemented with 6 to $12 \%$ lipid in the present study supported good growth of dog conch. Sargent et al. (1997) and Sargent et al. (1999) indicated that marine aquatic animals has a limited capacity to desaturate C18:3n-3 to EPA and DHA because marine aquatic animals lack $\Delta-5$ desaturase. Hence, DHA and EPA are essential dietary constituents for marine aquatic animals. Bautista-Teruel et al. (2011) documented that n-3 HUFAs such as DHA and EPA can potentially improve abalone growth. Dog conch requires higher $1.60 \% \mathrm{n}-3$ HUFA for superior growth performance.

\section{CONCLUSIONS}

In conclusion, based on the broken line analysis of final weight of L. canarium, the optimal dietary lipid requirement was found to be $5.6 \mathrm{~g}$ lipid $/ 100 \mathrm{~g}$ diet. The dietary lipids could supply essential fatty acid for $L$. canarium in this study. The growth of $L$. canarium was influenced by $n-3$ HUFA levels in the diets.

\section{Statement of conflict of interest}

The authors have declared no conflict of interest.

\section{REFERENCES}

AOAC (Association of Analytical Chemists). 1984. Official methods of analysis of the association of official analytical chemists, $14^{\text {th }}$ edn. AOAC. Inc., Arlington, VA, USA., pp.1141.

Bautista-Teruel, M.N., Koshio, S.S. and Ishikawa, M., 2011. Diet development and evaluation for juvenile abalone, Haliotis asinina Linne: Lipid and essential fatty acid levels. Aquaculture, 312: 172-179. https://doi.org/10.1016/j.aquaculture.2011.01.004

Bernhart, F.W. and Tomarelli, R.M., 1966. A salt mixture supplying the National Research Council estimates of mineral requirements of the rat. J. Nutri., 89: 495-500. https://doi.org/10.1093/jn/89.4.495

Chaitanawisuti, N., Kritsanapuntu. S. and Santaweesuk. W., 2011. Effects of dietary protein and lipid levels and protein to energy ratios on growth performance and feed utilization of hatchery-reared juvenile spotted Babylon (Babylonia areolata). Aquacult. Int. 19: 13-21. https://doi.org/10.1007/s10499-0109337-4

Chu, J.H., and Sheen, S.S., 2016. Effects of dietary lipid levels on growth, survival and body fatty acid composition of grouper larvae, Epinephelus coioides and Epinephelus lanceolatus. J. Mar. Sci. Technol. 24: 311-318.

Chu, J.H., Lan Y.W. and Sheen, S.S., 2018. The protein requirement for the juvenile dog conch, Laevistrombus canarium, in a recirculating aquaculture system. J. Fish. Soc. Taiwan, 45:261269.

Cob, Z.C., Arshad, A., Bujang, J.S. and Ghaffar, M.A., 2009a. Age, growth, mortality and population structure of Strombus canarium (Gastropoda: Strombidae): Variations in male and female subpopulations. J. appl. Sci., 9: 3287-3297. https://doi. org/10.3923/jas.2009.3287.3297

Cob, Z.C., Arshad, A., Ghaffar, M.A., Bujang, J.S. and Muda, W.W.L., 2009b. Development and growth of larvae of the dog conch, Strombus canarium (Mollusca: Gastropoda) in laboratory. Zool. Stud., 48: 1-11.

Cob, Z.C., Arshad, A., Bujang, J.S. and Ghaffar, M.A., 
2009c. Seasonal variation in growth and survival of Strombus canarium (Linnaeus, 1758) larvae. Pakistan J. biol. Sci., 12: 676-682. https://doi. org/10.3923/pjbs.2009.676.682

Cob, Z.C., Arshad, A., Sidik. J.B., Amin, S.M.N., and Ghaffar, M.A., 2008. Growth, mortality, recruitment and yield-per-recruit of Strombus canarium Linnaeus, 1758 (Mesogastropoda: Strombidae) from the West Johor Straits, Malaysia. Res. J. Fish. Hydrobiol., 3: 71-77.

D’Abramo, L.R. and Sheen, S.S., 1993. Polyunsaturated fatty acid nutrition in juvenile freshwater prawn, Macrobrachium rosenbergii. Aquaculture, 115: 63 86. https://doi.org/10.1016/0044-8486(93)90359-7

Folch, J., Lees. M. and Sloane-Stanley, C.H., 1957. A simple method for the isolation and purification of total lipids from animal tissue. J. biol. Chem., 226: 497-509.

Gallager, S.M., Mann, R., and Sasaki, G.C., 1986. Lipid as an index of growth and viability in three species of bivalve larvae. Aquaculture, 56: 81-103. https:// doi.org/10.1016/0044-8486(86)90020-7

Huang, C.H., Huang, M.C. and Hou, P.C., 1998. Effect of dietary lipids on fatty acid composition and lipid peroxidation in sarcoplasmic reticulum of hybrid tilapia (Oreochromis niloticus $\times O$. aureus). Comp. Biochem. Physiol., 120: 331-336. https://doi. org/10.1016/S0305-0491(98)10022-6

Huo, Y.W., Jin, M., Zhou, P.P., Li, M., Mai, M.K.S. and Zhou, Q.C., 2014. Effect of dietary protein and lipid levels on growth, feed utilization and body composition of juvenile swimming crab, Portunus trituberculatus. Aquaculture, 434: 151-158. https:// doi.org/10.1016/j.aquaculture.2014.08.011

Lee, S.M. and Lim, T.J., 2005. Effects of dietary protein and energy levels on growth and lipid composition of juvenile snail (Semisulcospira gottschei). J. Shellf. Res., 24: 99-102. https://doi.org/10.2983/07308000(2005)24[99:EODPAE]2.0.CO;2

Mai, K., Mercer, J.P., and Donlon, J., 1995. Comparative studies on the nutrition of two species of abalone, Haliotis tuberculata L. and Haliotis discus hannai Ino. III. Response of abalone to various levels of dietary lipid. Aquaculture, 134: 65-80. https://doi. org/10.1016/0044-8486(95)00043-2

Man In 'T Veld, L.A. and De Turck, K., 1998. Contributions to the knowledge of Strombacea. 6. A revision of the subgenus Laevistrombus Kira, 1955 including the description of a new species from the New Hebrides. Gloria Maris., 36: 73-107.

Metcalfe, L.D. and Schmitz, A.A., 1961. The rapid preparation of fatty acid esters for gas chromatographic analysis. Anal. Chem. 33: 363365. https://doi.org/10.1021/ac60171a016

Morais, S., Bell, J.G., Robertson, D.A., Roy, W.J. and Morris, P.C., 2001. Protein/lipid ratios in extruded diets for Atlantic cod (Gadus morhua L.): Effects on growth, feed utilization, muscle composition and liver histology. Aquaculture, 203: 101-119. https://doi.org/10.1016/S0044-8486(01)00618-4

NRC (National Research Council). 2011. Nutrient requirements of fish. National Academy Press, Washington, DC.

Poutiers, J.M., 1998. Gastropods. In Carpenter, K.E. The living marine resources of the Western Central Pacific. Food and Agriculture Organization of the United Nations (FAO), Rome. pp. 471.

Purchon, R.D. and Purchon D.E.A., 1981. The marine shelled Mollusca of West Malaysia and Singapore. Part I. General introduction and account of the collecting stations (abstract). J. Mollus. Stud. 47: 290-312.

Sargent, J.R., McEvoy, L.A. and Bell, J.G., 1997. Requirements, presentation and sources of polyunsaturated fatty acids in marine fish larval feeds. Aquaculture, 155: 117-127. https://doi. org/10.1016/S0044-8486(97)00122-1

Sargent, J.R., McEvoy, L., Estevez, A., Bell, G., Bell, M., Henderson, J. and Tocher, D., 1999. Lipid nutrition of marine fish during early development: current status and future directions. Aquaculture, 179: 217-229. https://doi.org/10.1016/S00448486(99)00191-X

Sheen, S.S. and D'Abramo, L.R., 1991. Response of juvenile freshwater shrimp, Macrobrachium rosenbergii, to different levels of a cod liver oil/corn oil mixture in a semi-purified diet. Aquaculture, 93: $121-134$. https://doi.org/10.1016/00448486(91)90211-O

Silver, G. R., Higgs, D. A., Dosanjh, B. A., McKeown, B. A., Deacon, G. and French, D., 1993. Effect of dietary protein to lipid ratio on growth and chemical composition of Chinook salmon (Oncorhynchus tshawytscha) in seawater. In: Fish nutrition in practice (eds S.J. Kaushik and P. Luquet). Les Colloques, Paris. pp. 459-468.

Thongrod, S., Tamtin, M., Chairat, C. and Boonyaratpalin, M., 2003. Lipid to carbohydrate ratio in donkey's ear abalone (Haliotis asinina, Linne) diets. Aquaculture, 225: 165-174. https:// doi.org/10.1016/S0044-8486(03)00287-4

Uki, N., Kemuyama, A., and Watanabe, T. (1985). Development of semi-purified test diets for abalone. Bull. Jap. Soc. Sci. Fish., 51: 1825-1833. 
https://doi.org/10.2331/suisan.51.1825

Vergara, J.M., Lopez-Calero, G., Robaina, L., Caballero, M.J., Montero, D., Izquierdo, M.S. and Aksnes, A., 1999. Growth, feed utilization and body lipid content of gilthead seabream (Sparus aurata) fed increasing lipid levels and fish meals of different quality. Aquaculture, 179: 35-44. https://doi. org/10.1016/S0044-8486(99)00150-7

Watanabe, T., 1982. Lipid nutrition in fish. Comp. Biochem. Physiol., 73B: 3-15. https://doi. org/10.1016/0305-0491(82)90196-1

Yoshii, K., Takakuwa, F., Nguyen, H.P., Masumoto, T. and Fukada, H., 2010. Effect of dietary lipid level on growth performance and feed utilization of juvenile kelp grouper Epinephelus bruneus. Fish. Sci., 76: 139-145. https://doi.org/10.1007/s12562009-0191-0

Zhou, Q.C., Zhou, J.B., Chi, S.Y., Yang, Q.H. and Liu, C.W., 2007. Effect of dietary lipid level on growth performance, feed utilization and digestive enzyme of juvenile ivory shell, Babylonia areolate. Aquaculture, 272: 535-540. https://doi. org/10.1016/j.aquaculture.2007.07.236 